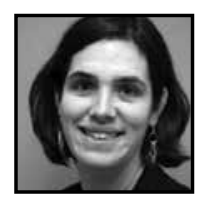

\title{
The Role of Field Experiences in the Professional Socialization of Early Career Literacy Teachers
}

\author{
Katrina Bartow Jacobs, University of Pittsburgh
}

\begin{abstract}
Scholarship on field experiences often addresses issues of integration with coursework and the development of students' pedagogical knowledge, with less focus on their role in the development of teachers' professional identities. Drawing on data from a yearlong qualitative study, this article addresses a central concern for students in a literacy teacher preparation program-fieldwork as a lonely venture. This research suggests that traditional field experiences explicitly and implicitly perpetuate images of teaching as a solitary act. These findings highlight the need to reconceptualize field experiences as sites of inquiry in order to disrupt narratives of isolation within teacher education.
\end{abstract}

\section{Introduction}

“Often field placement feels like, feels like being a visitor in a stranger's home. I'm learning the context, learning what's expected, trying to take it all in and participate at the same time. Trying to be a teacher, you know? And I just, I just wish I knew what other people were experiencing too. I feel I could learn a lot from that." (Ava, ${ }^{1}$ Interview, October 6, 2012)

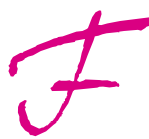

ield experiences have long been an integral aspect of teacher education, and of professional schooling more broadly. Historically, research and scholarship on the topic of fieldwork has focused on its integration with coursework, with a direct focus on the development of content and pedagogical knowledge (Cochran-Smith \& Zeichner, 2005; Darling-Hammond, 2012). While this
} 
focus has provided the field with a great deal of knowledge regarding the ways that early career teachers come to understand and enact pedagogy, there has been less attention paid to ways that field experiences are structured, as well as the impact of these experiences on teachers' socialization and understanding of their role within a school community (for notable exceptions, see Moore, 2003; Tiezzi \& Cross, 1997; Zeichner, 2010). In the study described in this article, participants routinely addressed the widely varying nature of how field experiences were constructed, enacted, and experienced-both within previous teacher preparation programs they had attended, and at the program they were participating in during the course of this study.

The research presented in this article stems from a year-long qualitative study into the impact that field placements had on students in a literacy teacher preparation program. It shows the ways that learning about pedagogical and content knowledge (Segall, 2004; Shulman, 1986) was inextricably linked to experiences of "real life as a teacher" within field experiences, and the complicated ways that these experiences impacted early career teachers' socialization to the career of a literacy education.

The responses of the participants in this study demonstrate the deep impact these frameworks had on the participants' engagement, reflections, and integration of these experiences into their larger teacher education program, and ultimately into their own developing identities as literacy educators.

This article offers an investigation into a central concern for the participants in this study - the sense of fieldwork as a lonely venture. In both their reflections on previous experiences and their narratives around their current placements, participants repeatedly referenced their sense of isolation within fieldwork. Overall, this research suggests that traditional field experiences, even in programs designed to be collaborative and inquiry-based, continue to perpetuate the lesson that teaching is a solitary act.

Finally, I suggest that a model for field experiences that explicitly explores the situated and local nature of these placements, as well as positioning them within deliberate and sustained inquiry communities (Cochran-Smith \& Lytle, 1999, 2009) in teacher preparation programs, can shift how teacher learners experience their classroom-based contexts and move toward a more collaborative and dialogic image of teaching. 


\section{Prior Literature: Field Experiences as a Unique Space of Learning}

The notion that school-based and community-based learning, in the form of field experiences, should occur during teacher preparation programs is so ubiquitous that it has remained almost unquestioned within the literature (Zeichner, 2006, 2010). There is, however, a wide range of what is counted as "field-based learning"_-including how these spaces are constructed, the goals of the schools and universities, and the objectives and experiences of the students within the programs. Within the past few decades, there has been a move toward refocusing teacher education, pushing for a more "practice-based" approach for pre-service teacher education (Ball \& Cohen, 1999; Ball, Sleep, Boerst, \& Bass, 2009; Darling-Hammond, 2006) in which field experience and "real world knowledge" are emphasized throughout and in conjunction with coursework. This shift in focus alters the ways that fieldwork is contributing as a space of learning, as well as the ways that it can, and should be, studied as an integral part of teacher education.

Although the increased focus on school-based learning has increased research and policy attention to fieldwork (Darling-Hammond, 2012; Zeichner, Payne, \& Brayko, 2012), certain assumptions about the role of these spaces, as well as the ways that relationships and knowledge are conceptualized, have not been addressed as directly. In particular, there remain unspoken assumptions about the connections between the school and university communities, as well as larger issues related to the relationships of theory and practice (Cochran-Smith \& Lytle, 1999; Zeichner, 2012). These assumptions often highlight the theory/practice divide, where universities are sites for learning theory, whereas schools are seen as places to learn to apply these theories in practice. As such, this framework has limited the ways in which the scope of research on these fieldwork experiences has been conceptualized in relation to teacher education programs. In other words, while many authors have reflected on the ways in which field experiences within a particular course have impacted teachers' beliefs or understandings about the nature of teaching and education (Cochran-Smith, Barnatt, Friedman, \& Pine, 2009; Moore, 2003; Zeichner, 2010), less attention has been paid to how these field experiences have been related to overarching program missions, goals, and mandates.

Clift and Brady (2005) offer an analysis of research into field experiences in literacy classrooms: they note that research has paid little attention to the development and role of field experiences as part of the cohesive teacher education programs. This research reflects these concerns, particularly around the ways that some of the unquestioned 
structures of fieldwork implicitly perpetuate certain status quo understandings about the structures of schools and the nature of the profession, such as the concept of teaching as a solitary act, or the image of a teacher as an unquestioned expert, even when these messages are being contradicted in coursework.

In addition, while much theoretical and empirical work in teacher education addresses the importance of taking into account the expectations that teacher learners bring with them to teacher education contexts (Carter, 1993; Cochran-Smith, 1995; Grouws \& Schultz, 1996; Lee, 2013), this issue has been less directly addressed in research specifically related to field experiences. Students' expectations include not only the nature of these experiences and their relationship to coursework, but also to the individual's career goals, previous histories as a student and educator, and their familiarity with the community contexts in which they are placed (Gay, 2010; LadsonBillings, 2001; Milner, 2012; Sleeter, 2001; Zeichner, 2010). All of these issues come into play in the experience of field placements, yet there remain questions regarding the complicated ways in which these experiences frame the development of early career literacy teachers' professional identities (Moore, 2003; Lasky, 2005).

\section{Conceptual Frameworks}

As this study explores both the nature of literacy education and the narrative practices of the participants, I situate this work with a sociocultural perspective on literacy that acknowledges the importance of local context in relation to knowledge and meaning-making. Instead of viewing literacy as a set of skills that can travel from context to context without change-what Street refers to as the "autonomous model" of literacy (Street, 1984, 2003) — this article frames literacy as a much more intimate process, one that influences and is influenced by community, history, and audience. This focus also relates to a theoretical understanding of the complex relationship of theory and practice. Building from Cochran-Smith and Lytle's (1999) concept of "knowledge of practice," which emphasizes the dialogic nature of theory and practice, this study explores the socialization process of field experiences within the belief that our actions are always more or less guided by conscious ways of understanding and organizing the world. This study is framed by the belief that regardless of specific contexts, people are always guided by their understandings as well as their previous experiences. These theories or "ways of knowing" impact their experiences, identities, and ways of communicating their lives-especially in the work as teachers and teacher educators (Buck \& Sylvester, 2013; Cochran-Smith \& Zeichner, 2005). 
It is critical, however, to consider not only how people utilize their literacy practices, but also what practices are made available to them, and what practices are valued within various settings. Lewis, Enciso, and Moje (2007) argue that we must reframe sociocultural research on literacy to include a discussion of identity and agency.

This work draws on the recent interest in teacher socialization and identity that highlights the complicated development of these attributes, focusing on the ways that they are multiple, discontinuous, and inherently social (Akkerman \& Meijer, 2011; see also: Alsup, 2006; Beauchamp \& Thomas, 2009; Beijaard, Meijer, \& Verloop, 2004; Cochran-Smith, Feiman-Nemser, Mclntyre, \& Demers, 2008).

Taking this stance on literacy, learning, and teacher identity shifts the ways that field experiences might be conceptualized as a space of learning within teacher education. One of the most interesting aspects of fieldwork in this regard is its potential to disrupt the traditionally understood university/school divide. As such, field experiences act as a kind of borderland where students are actively crossing contexts, bringing their own experiences, knowledge, and identities with them as they transition from one space to another, leading often to a series of contact zones (Pratt, 1991). Anzaldúa (1999) discusses the importance of borders that are "set up to...distinguish us from them... A borderland is a vague and undetermined place created by the emotional residue of an unnatural boundary. It is in a constant state of transition" (p. 25). This framework highlights the political issues within field placements; a focus on borders offers a more explicit and critical perspective not only on the physical transitions, but also on the issues of power and agency in the development of early career teachers (Giroux, 1992). I conceptualize fieldwork as a borderland space where negotiations can be made more explicit, assumptions can be brought into question, and participants might need to engage in active negotiation of meanings, rather than assume unchallenged definitions. Given this unique location, fieldwork becomes a rich site from which to reflect on how teachers take up concepts from coursework and activities or understandings from the community in relation to their own histories as they make sense of their own positions, the possibilities for pedagogical practices in literacy education, and their careers as literacy educators.

\section{Research Questions}

This study's main research question is: How do master's students in a literacy education program work together to narrate and make sense of fieldwork as a space of learning about teaching? More specifically, this paper addresses the following question: 
1) How do field experiences impact the development of early career literacy teachers' professional identities?

\section{Methodology}

\section{Participants and Context}

Data for this study came from a year-long qualitative research project centered on an inquiry group that met every two weeks through the September 2012-May 2013 academic year to discuss field experiences. The group consisted of 12 master's students in a graduate literacy program, many of whom were also working toward their reading specialist certification at a private university located in a large North American city. Group members had a range of teaching experiences, from no formal professional background in education, to some student teaching experience, to up to five years as a classroom teacher. Although I saw myself as an active participant in the group, I also had to acknowledge my own positionality within the larger program. At the time of the study, I was an advanced doctoral student in the same program as the participants. My decision to carry out this research and form this inquiry community stemmed from both my own teacher preparation experiences and from my work as a fieldwork coordinator and instructor within the master's program. Indeed, nine of the participants were enrolled in the course I taught on literacy assessment during the time of the study. While my central goal for the project was to investigate how these participants made sense of and narrated their field experiences, I also believed that convening an inquiry community of this nature would be an asset to both the individual students and the program as a whole.

The literacy master's program had an explicit focus on issues of social justice, urban education, and sociocultural perspectives on literacy and literacy education. ${ }^{2}$ Furthermore, the program tried to address collaborative learning and professional development throughout the courses, with a strong focus on teacher research and practitioner inquiry. Shorter field experiences were embedded in many of the core classes and two specific "fieldwork" practicum courses were requirements-one in the fall and one in the spring-where students engaged in a more traditional intensive experience within one K-12 literacy-centered classroom. In these practicum courses, graduate students were placed in either a literacy teacher or a reading specialist and asked to observe and participate in the planning, implementation, and assessment of literacy instruction for individual students, as well as small- and whole-group sessions. As a part of the practicum course, the graduate students also had a weekly seminar 
where they discussed readings, shared lessons plans, and received information about curriculum design and classroom organization.

In addition to the inquiry group meetings, seven people were individually interviewed three times over the course of the 2012-2013 year (October, January, and May) for a total of 21 interview sessions, each lasting between 45 and 60 minutes. These semi-structured interviews offer more of an ongoing and individualized understanding of how field experiences and participation in the inquiry group might have influenced the master's students' perceptions of their roles and responsibilities around literacy education.

\section{Data Sources and Analysis}

Data for this study was drawn from a variety of sources. At each inquiry group session two participants shared a narrative from their respective field placement, which then led into more general dialogue and conversation. During the 13 inquiry group meetings, extensive fieldnotes were taken that focused directly on participants' talk (Emerson, Fretz, \& Shaw, 2011). These fieldnotes highlighted the individual narratives that participants shared, as well as the ways that the group engaged collectively in discussion of the issues that arose from these stories. Each of the 21 interview sessions was audiorecorded and then transcribed verbatim. In addition, written and visual artifacts were collected that either emerged from the group sessions (in the form of emails, notes, and collaboratively constructed charts); were brought by participants from field placements to inquiry group meetings (students' writing, journals, drawings, etc.); or that were created by participants and shared with me individually (personal journals, emails, etc.). Participants were offered the chance to provide member checks (Marshall \& Rossman, 2010), in the form of follow-up discussions and a chance to comment on any written work or presentation drafts that emerged from the study.

I coded the data using an inductive approach that aimed to uncover emergent themes (Strauss \& Corbin, 1997) with a particular focus on how participants constructed narratives (Clandinin, 2006; Connelly \& Clandinin, 1999) about themselves as teachers, their field experiences, and the schools they visited. Data analysis occurred during two phases. The first occurred during data collection (September-May) and involved the development of emergent codes, as well as deliberate attention paid to the a priori codes and questions that I brought with me to the data. For example, while I knew I was interested in issues of socialization and professional identity, it was the stories shared and subsequent group dialogue that led me to codes such as fieldwork as isolating; loneliness of teaching; and fieldwork learning beyond curriculum. 
During the second phase of data analysis, I utilized the constant comparative method (Lincoln \& Guba, 1985) as I looked across the data and the 17 codes that had emerged during phase one to explore persistent themes. More specifically, I focused on how the group members and interviewees utilized narrative within group discourse as a way of engaging in these experiences (Clandinin, 2006; Wortham \& Gadsden, 2006; Casey, 1995). By focusing on the participants' "thematic narratives" (Emerson, Fretz, \& Shaw, 2011), as well as the "multivoiced nature of teaching and the multisensual nature of teaching and learning" (Clandinin, 2006, p. 375), I gained a deeper understanding of how these narratives represented emergent and developing understandings of literacy education and professional identity through their field experiences.

\section{Findings}

Overall, the findings from this study demonstrate how both the structure and the focus of field experiences within teacher education implicitly and explicitly perpetuated the message that teaching is an isolated act. While this sense of isolation has been noted in earlier research on teacher education (Britzman, 1991; Hoy, 2008), this study specifically explores how these issues are embedded within field placements as a space of professional learning. Field experiences impacted teachers' socialization and created a sense of isolation in two different, but related, ways: 1) the perception of field placements as a "proving ground" of one's professional abilities, particularly in relation to certification; and 2) the ways in which the field placement course only directly addressed certain aspects of their school-based experiences. In particular, those aspects directly related to content instruction and classroom management, which left participants uncertain of how to make sense of other narratives from their time in schools.

\section{Field Experiences as a Solitary "Proving Ground"}

Field placements and practicum courses are often conceptualized in teacher education as a place of collaboration and community (Cohen, Hoz, \& Kaplan, 2013; Zeichner, Ball, \& Tyson, 2011). Yet, within the early inquiry group sessions, it quickly became clear few participants felt this way. In fact, in our very first meeting, the teacher learners identified the deep sense of isolation that permeated many of their field experiences: 
Emily: [My undergrad fieldwork] and first year of teaching were much the same. You're by yourself. Just supposed to know what to do. It's just overwhelming and exhausting. It's just so easy in those moments to get away from the aspirations. I got caught up in the day-to-day stuff. I thought it would be better once I was the teacher, but both times I felt isolated, alone, and overwhelmed. So many friends who went through it with me - we all had these feelings. ... I feel like, you're just tossed in the way we do teacher education. Like, we taught you this in classes. Go show me you can do it yourself.

Lila: I agree. Alone is a word that comes up a lot in fieldwork, especially here. I feel like I go into the classroom where I am supposed to help teaching reading, writing, literacy - but that's my weak point. The teacher assumes I have knowledge because I'm a master's student. But I don't feel I have it. (Fieldnotes, Inquiry Group Meeting 1)

In these early moments together, the participants were already describing a sense of vulnerability in their field experiences. Often the participants did not know who to turn to when they were uneasy or uncertain, or felt that they were expected to be able to address these issues alone. In many ways, this sense of isolation highlights some of the anxieties described in the above sections: the sense that fieldwork is the proving ground that one has "made it" as a teacher, or the concern that somehow fieldwork experiences fall both outside of the school and university culture, leaving teacher learners to find their own paths through the experience. This loneliness seemed to relate both to the fact that they were not only physically separate from their peers in these spaces - navigating these day-to-day interactions and relationships very much by themselves-but also that they felt responsible to be experts by the time they entered schools. This anxiety speaks to the issues with framing fieldwork, especially student teaching or practicum work, as the "proving ground" of capability and knowledge.

In her seminal work Practice Makes Practice (1991, 2005), Deborah Britzman refers to this side of teaching as the "myth of the lone individual":

An identity that bestows valor on the lonely process of becoming a teacher, but at the same time suppresses the social meanings and forces that beckon the subject as a lone individual. While individual effort is, of course, a necessary condition in learning to teach, so too are social negotiations, interactions, and social dependence. Yet the normative discourse of teacher education masks such complexity both by positioning the process of learning to teach as "sink or swim" and stigmatizing negotiation. (p. 235) 
Britzman's work highlights the ways this emphasis on individuality reinforces the ways that education and teaching are currently structured: because teachers are explicitly and implicitly told that they are on their own, they fall back on the expectations that are most clearly laid out by mentor teachers, university supervisors, or on their own memories and histories as students themselves. While Britzman's work is not new to the field of teacher education, it is apparent that many of the myths she highlights remain true for today's early career teachers. For example, Emily, the most seasoned teacher in the group with five years' teaching experience, shared at this first meeting:

When I was in undergrad, doing my student teaching, I knew I hated school the way it had been done. I swore I wouldn't do it that way. But then there was so much pressure. I had to get my certification, and I thought that's what they were looking for. So that's what I did. And here, learning to be a reading specialist, I'm doing again. I'm watching myself doing it again.

Savannah: Yes. Me too. I mean, I don't have your experience, but I know the feeling. It's like becoming your parent, or something. But then in the classroom it's just me and I don't know what else to do. (Fieldnotes, Inquiry Group Meeting 1)

Bullock (2011) describes how these myths and pressures perpetuate throughout teacher education programs, deeply coloring the ways that teacher learners conceptualize and approach the act of becoming a teacher. Field placements, both because they are situated within the daily world of schools and their connection to certification, are possible sites of disruption or of maintaining the status quo of education. These data show that these learning spaces, as they are often structured within teacher preparation programs, can subtly but forcefully maintain the sense that teachers must go it alone, without questions, doubt, or community.

Participants came to their practicum with a deep appreciation for these issues, as well as the ways that they are particularly salient within their lived experiences of fieldwork in schools. They frequently articulated in powerful ways how this sense of isolation followed them into their field sites and deeply impacted how they imagined their own work as teachers. In one of our later meetings, after sharing a story about a lesson that did not go as planned, Abby was asked by the group who she went to for feedback. She replied:

It's funny, because I'm the only one there. I mean, I guess the teacher and my mentor are there too, but really - it's just me when it comes to putting it all together. And we 
[participants in the graduate literacy program] talk, but just venting - not like, professional support. It frustrates me a lot. I wish it were easier. But it also means I have agency, and I like that. ... Maybe it's good to have trial by fire. Maybe I should appreciate more the chance to create the space for myself, to take up my own inquiry. But I don't know. Right now it feels like I'm alone and to sink or swim and nobody will notice unless I've already drowned. (Field Notes, Inquiry Group Meeting 7)

Even in a program that explicitly values collaboration and dialogic approaches to knowledge production, the underlying structures of the field placements continue to implicitly enforce the idea that teaching is a solitary act. Furthermore, as field placements are seen-and act in reality-as the final hurdle before certifications, understandably teacher learners come to these spaces with heightened anxiety and concern about how they are perceived, at times leading them to ask for less guidance and support.

\section{Field Experiences in the "Second Classroom": Professional Learning in the Margins}

Frequently, this concept of loneliness was not only about being the only university student in a particular school, but went much more deeply into the professional lessons the students were learning and observing during their field placements. Often, these issues came up not in discussion of particular lessons, but instead in relation to the conversations with mentor teachers. Savannah described that after finishing student teaching and starting as a teacher in her own classroom, she had learned to "stay in her bubble and do what she was doing" (Field notes, Inquiry Group 4). Veronica went so far as to share the following conversation from her undergraduate experience:

My cooperating teacher - with her, I learn how to stay out of the halls. She told me not to go to the teacher lounge, or they would find me. I didn't even know who 'they' were, but I definitely stayed in my classroom after that, and kept it that way when I was teaching myself. (Interview, January 15, 2013)

Here, the participants described fieldwork as lonely not only in terms of their day-today experiences of going to schools by themselves, seeking places to describe these experiences with peers and university educators, but also the deep impact that these impressions or framings had on their future careers. Furthermore, participants often referenced experiences and narratives that lay outside of the part of the school day directly involved with instruction-as well as the fact that these moments were never directly addressed in their teacher preparation programs: 
Mark: The teacher I was with last semester for fieldwork, he talked about a meeting with a superintendent. He didn't listen to them, didn't answer any questions. Now, Northeast High is one of the schools scheduled to be closed. ${ }^{3}$

Max: See, this is why, I think in teacher education we should be educating in educational politics. Issues so classroom based, but we don't go up the pipeline on how that works. Fieldwork lets you see some of that stuff too.

Abby: Right. It shows you the professional inner workings on being a teacher. When I was doing my internship, teachers were working without a contract. I couldn't go to meetings, but I would hear teachers talking about issues. I had never heard about them before, never considered them. I knew nothing about unions, about being a part of teacher union. We take education policy classes, but it's all history. Not current politics behind it all.

Max: That's why I like hanging out with teachers at fieldwork, between classes not just about how to teach, but also how to manage yourself in school. Not always in the best interest of you as a teacher, or you as a school. Even not always in best interests of your students, but sometimes in the best interests of keeping your job. (Fieldnotes, Inquiry Group Meeting 8)

These moments show that beyond the expected lessons around curriculum, classroom management, and pedagogical decision-making, fieldwork is also the space of learning about the ethos of teaching, schooling, and learning. The students frequently talked about the power of seeing not just classroom practice, but also school practices and culture as inextricably linked to lesson plans and classroom management.

In describing the spaces for students and teachers to engage in the deeply personal, political, and historical work of literacy learning and practice, scholars have conceptualized the classroom as functioning along multiple levels (Campano, 2007, Gutiérrez, 2008). Campano (2007) refers to this space for more personal and localized learning as the "second classroom", a space "that occurs during the margins and in between periods of the school day... The second classroom runs parallel to, and is sometimes in the shadow of, the official first classroom. It is an alternative pedagogical space" (pp. 39-40). During their fieldwork hours, teacher learners do not simply experience the curriculum and pedagogical practices that make up the instructional hours frequently thought of as "teacher's work," but also visit and participate in these marginalized spaces as well. Closely related to the concept of the "third space" within schools (Gutiérrez, 2008; Moje et al., 2004), these experiences also have lasting impacts on the participants' identities and perspectives as teachers, often highlighting topics and issues that are rarely, if ever, addressed in the "first classroom" focus of teacher 
education programs. While the framework of the "third space" has become more popular in recent scholarship in K-12 settings, this finding demonstrates the importance of thinking about teacher education and field experiences from this more situated and localized perspective, in order to better prepare teachers to engage students holistically and to draw more broadly on a richer and more nuanced perspective of literacy education and learning. This framework makes inquiry and uncertainty a facet of their professional identity, rather than a weakness to be avoided.

Beyond content area knowledge, pedagogical practices, and classroom management strategies, a critical but under-researched area of fieldwork occurs during these "off times," when teachers talk in halls or in staff lounges. These moments make up a "second classroom" within field placements; frequently, it is during these conversations that deep issues of power, professionalism, and teacher identity were addressed most explicitly during the participants' field placements. Yet, these spaces go largely unrecognized by the official focus on fieldwork in the university, often adding to the sense of isolation that the participants described above as they struggled individually to bridge these experiences and make sense of their fieldwork as a space of professional learning. As previously shared by Veronica, often these experiences are puzzling, overwhelming, or downright terrifying to early career teachers or teacher learners. Without the space to discuss these moments within teacher preparation programs, teacher learners lack the community to engage in collaborative inquiry around these issues, rendering them taboo or unspoken within their preparation as literacy educators.

In addition to addressing the importance of these spaces as an element of fieldwork, the inquiry group also addressed how loneliness, isolation, and politics follow teachers into their classrooms after graduation. In particular, participants frequently worried about how and where they could gain support once they were in their own classrooms:

Savannah: You know, it's so sad when we get students who we think are behind. We think it's so sad and they are not getting support at home. We blame the kids; we blame the families. But since being in fieldwork this semester, I've changed my perspective a little bit. ...The teachers they are just so down. I know teachers aren't solely to blame, but I've had a change of heart. What happened to them?

Max: I agree, but I also think, no man's an island. No teacher's an island. I mean, they operate in schools, in communities. (Fieldnotes, Inquiry Group Meeting 6) 
Emily: A lot happens your first year [teaching] and you don't know what to do, or how to read it. But you're afraid if you ask people they will be catty, or make fun of you. But you need answers. And if you hear enough of that — that you're not doing it right but you don't know who to ask — it can weigh on you. It can burn you out.

Genevieve: At my school, where I taught last year, there were fifteen classrooms. Before they started a mentoring program six teachers left. That was by midyear. It was better when we made official time to talk things through. (Fieldnotes, Inquiry Group Meeting 10)

In these moments, the participants share their deep awareness, and apprehension, of the "Ione individual" ethos that Britzman (1991) describes. They are highly aware of the politicized nature of teaching, the ramifications of asking for support, and the high rate of "burnout" for teachers, particularly those who work in under-resourced schools. In many ways, the participants viewed fieldwork as a space where one could learn about these issues and gain support before being the teacher of record in a classroom. Yet, just as frequently they described concerns bringing those issues back to the universityoften referencing how the assignments for the fieldwork course focused more on specific lesson plans or assignments, rather than on these less structured spaces within school settings. These findings highlight some of the ways that unquestioned or takenfor-granted aspects of field experiences and how they are structured within teacher education need to be reexamined and, where possible, restructured to foster in teacher learners a more collaborative and inquiry-based understanding of learning to teach.

\section{Reframing Field Experiences as Collaborative Inquiry}

Throughout our work together as an inquiry group, and in individual interviews, participants often shared stories about feeling isolated during their field experiences, with a sense that their experiences were unique and at times fragmented, especially in relation to the university courses. Often, this sense of loneliness or isolation was compounded by the framing of fieldwork as a final space to prove one's knowledge and preparation before becoming a teacher. Participants also described the ways that narrating their particular context and discussing it with others help alleviate some of these concerns, as well as their desire to find spaces to have ongoing conversations not just about instructional time, but also about discussions with teachers and experiences in the hallways and teacher lounges. 
These findings suggest that in many ways the idiosyncratic nature of fieldwork reflects the inherently messy, relational, and locally contextualized nature of teaching. Rather than frame these aspects of fieldwork as challenges to be overcome, these moments represent inherent facets of teaching that need to be discussed and considered during teacher education programs. Indeed, when given the opportunity to discuss these experiences with their peers, participants were able to both express a critical perspective on their own understandings of literacy, urban education, and their own development as educators while also questioning and probing each other's sense-making and perspectives. In addition, creating the space to collaboratively discuss these moments helped alleviate some of the loneliness and anxiety that they faced in their field experiences. As Mark shared in our final interview, "I knew-I mean, I knew I was never going to learn it all in fieldwork, even if I felt like I should. But talking about that-asking those questions and getting those head nods - that made me okay with that" (Interview, May 26, 2013). These findings demonstrate that in addition to teaching students how to approach methods and pedagogical knowledge within their teacher preparation, field experiences can also function as a space to help students contextualize that work within their school-based experiences and in terms of their own development as teachers.

Engaging in conversations about the nature of learning in fieldwork provided students with an opportunity to develop a greater appreciation for the ways in which these experiences and narratives influenced their own work and perspectives as educators. Yet, this study also shows that identity work does not take place in isolation. The program that this inquiry group was situated within-and the structure of the inquiry community itself-attempted to complicate the hierarchies of expert and novice by engaging students with a range of teaching experiences and backgrounds in a collective dialogic space around issues related to field experience. One of the goals of the study was for this group to work together to explore teaching and teacher education through an "inquiry stance" (Cochran-Smith \& Lytle, 1999, 2009) which encourages teachers to see themselves as researchers of their own practice, questioning their assumptions and constructing knowledge of their own contexts. Within the structure of field placements, this inquiry framework can provide a:

Richer conception of knowledge than that allowed by the formal knowledgepractical knowledge distinction, an expanded conception of practice as both practical and theoretical, and a fuller conception of teacher learning across the professional life span than that implied by the expert/novice distinction. (CochranSmith \& Lytle, 1999, p. 19) 
Building on this understanding of knowledge and practice, this study was designed not only to better understand how field placements impacted the participants' sense of the literacy classroom, but also to construct a space where we could engage together around how field experiences - in conjunction with our own histories and other workwere impacting perceptions of both what it means to be a teacher education student, and on how we all were constructing and reconstructing our images and identities as teachers.

These findings emphasize the importance of developing spaces that foster sustained, dialogic, and critical conversation among teacher learners. This kind of dialogue is particularly important in reference to fieldwork, a highly contested, complicated, and sometimes isolating space of learning. While field placements and practicum courses certainly can-and should-emphasize the importance of content and pedagogical knowledge, they also need to acknowledge the other types of professional learning that occurs within these spaces, thinking how these experiences impact early career teachers' socialization and professional identity development. In order to shift the status quo and disrupt the narrative of the teacher as "lone intellectual" (Britzman, 1991), teacher preparation programs can try to construct field experiences as collaborative inquiry-utilizing the development of "communities of practice" (Cochran-Smith \& Lytle, 1999) within teacher education-to help shift how literacy educators see the scope of their work and the role of community and collaboration within their own professional growth.

\section{Notes}

1. All names of people and places in this paper are pseudonyms.

2. These issues are explicitly highlighted on the program's website, as well as addressed in the title of many of the core courses that students are required to take toward their master's degree.

3. At the time of this study, the urban school district where most of the participants were in field placements was undergoing a serious budget crisis, leading to severe cutbacks and the scheduled closing of over 30 schools at the end of the year. 


\section{References}

Akkerman, S. F., \& Meijer, P. C. (2011). A dialogical approach to conceptualizing teacher identity. Teaching and Teacher Education, 27(2), 308-319.

Alsup, J. (2006). Teacher identity discourses: Negotiating personal and professional spaces. Routledge.

Anzaldúa, G. (1999). Borderlands: The New Mestiza / La Frontera (2nd ed.). San Francisco: Aunt Lute Books.

Ball, D., \& Cohen, D. (1999). Toward a practicebased theory of professional education: Teaching as the learning profession. San Francisco: Jossey-Bass.

Ball, D. L., Sleep, L., Boerst, T. A., \& Bass, H. (2009). Combining the development of practice and the practice of development in Teacher Education. The Elementary School Journal, 109(5), 458-474.

Beauchamp, C., \& Thomas, L. (2009). Understanding teacher identity: An overview of issues in the literature and implications for teacher education. Cambridge Journal of Education, 39(2), 175-189.

Beijaard, D., Meijer, P. C., \& Verloop, N. (2004). Reconsidering research on teachers' professional identity. Teaching and Teacher Education, 20(2), 107-128.

Britzman, D. P. (1991). Practice makes practice: A critical study of learning to teach. SUNY Press.

Britzman, D. P. (2005). Practice makes practice: A critical study of learning to teach, 2nd edition. SUNY Press.

Buck, P., \& Sylvester, P. S. (2013). Coupling funds of knowledge research and critical pedagogy in teacher education. In N. González, L. C. Moll, \& C. Amanti (Eds.), Funds of knowledge: Theorizing Practices in Households, Communities, and Classrooms (pp. 213-232). New York: Routledge.

Bullock, S. M. (2011). Becoming a Teacher. In Inside Teacher Education (pp. 1-10). Springer.

Campano, G. (2007). Immigrant students and literacy: reading, writing, and remembering.
New York: Teachers College Press.

Carter, K. (1993). The place of story in the study of teaching and teacher education. Educational Researcher, 22(1), 5-18.

Casey, K. (1995). The new narrative research in education. Review of Research in Education, 211-253.

Clandinin, D. J. (Ed.). (2006). Handbook of narrative inquiry: Mapping a methodology. Thousand Oaks, CA: Sage Publications.

Clift, R. T., \& Brady, P. (2005). Research on methods courses and field experiences. Studying Teacher Education: The Report of the AERA Panel on Research and Teacher Education, 309-424.

Cochran-Smith, M. (1995). Uncertain allies: Understanding the boundaries of race and teaching. Harvard Educational Review, 65(4), 541-571.

Cochran-Smith, M., Barnatt, J., Friedman, A., \& Pine, G. (2009). Inquiry on inquiry: Practitioner research and student learning. Action in Teacher Education, 31(2), 17-32.

Cochran-Smith, M., Feiman-Nemser, S., Mclntyre, D. J., \& Demers, K. E. (2008). Handbook of research on teacher education: Enduring questions in changing contexts. New York: Routledge.

Cochran-Smith, M., \& Lytle, S. L. (1999). Relationships of knowledge and practice: Teacher learning in communities. Review of Research in Education, 249-305.

Cochran-Smith, M., \& Lytle, S. L. (2009). Inquiry as stance: Practitioner research for the next generation. New York: Teachers College Press.

Cochran-Smith, M., \& Zeichner, K. M. (2005). Studying teacher education: The report of the AERA panel on research and teacher education. New York: Routledge for AERA.

Cohen, E., Hoz, R., \& Kaplan, H. (2013). The practicum in preservice teacher education: a review of empirical studies. Teaching Education, 24(4), 345-380. 
Connelly, F. M., \& Clandinin, D. J. (1999). Shaping a professional identity: Stories of educational practice. New York: Teachers College Press.

Darling-Hammond, L. (2006). Constructing 21st-century teacher education. Journal of Teacher Education, 57(3), 300-314.

Darling-Hammond, L. (2012). Powerful teacher education: Lessons from exemplary programs. New York: John Wiley \& Sons.

Emerson, R. M., Fretz, R. I., \& Shaw, L. L. (2011). Writing ethnographic fieldnotes. Chicago: University of Chicago Press.

Gay, G. (2010). Acting on beliefs in teacher education for cultural diversity. Journal of Teacher Education, 61(1-2), 143-152.

Giroux, H. A. (1992). Border crossings: Cultural workers and the politics of education. New York: Routledge.

Grouws, D. A., \& Schultz, K. A. (1996). Mathematics teacher education. Handbook of Research on Teacher Education, 2, 442-458.

Gutiérrez, K. D. (2008). Developing a sociocritical literacy in the third space. Reading Research Quarterly, 43(2), 148-164.

Hoy, A. W. (2008). What motivates teachers? Important work on a complex question. Learning and Instruction, 18(5), 492-498.

Ladson-Billings, G. (2001). Crossing over to Canaan: The journey of new teachers in diverse classrooms. New York: The Jossey-Bass Education Series.

Lasky, S. (2005). A sociocultural approach to understanding teacher identity, agency and professional vulnerability in a context of secondary school reform. Teaching and Teacher Education, 21(8), 899-916.

Lee, D. K. (2013). Teacher education for democracy and social justice. New York: Routledge.

Lewis, C., Enciso, P., \& Moje, E. B. (2007). Reframing sociocultural research on literacy: Identity, agency, and power. Mahwah, NJ: Lawrence Erlbaum.

Lincoln, Y. S., \& Guba, E. G. (1985). Naturalistic inquiry. Thousand Oaks, CA: Sage.
Marshall, C., \& Rossman, G. B. (2010). Designing qualitative research. Thousand Oaks, CA: Sage.

Milner, H. R. (2012). Challenges in teacher education for urban education. Urban Education, 47(4), 700-705.

Moje, E. B., Ciechanowski, K. M., Kramer, K., Ellis, L., Carrillo, R., \& Collazo, T. (2004). Working toward third space in content area literacy: An examination of everyday funds of knowledge and discourse. Reading Research Quarterly, 39(1), 38-70.

Moore, R. (2003). Reexamining the field experiences of preservice teachers. Journal of Teacher Education, 54(1), 31-42.

Pratt, M. L. (1991). Arts of the contact zone. Profession, 33-40.

Segall, A. (2004). Revisiting pedagogical content knowledge: The pedagogy of content/the content of pedagogy. Teaching and Teacher Education, 20(5), 489-504.

Shulman, L. S. (1986). Those who understand: Knowledge growth in teaching. Educational Researcher, 4-14.

Sleeter, C. E. (2001). Preparing teachers for culturally diverse schools: Research and the overwhelming presence of whiteness. Journal of Teacher Education, 52(2), 94.

Strauss, A., \& Corbin, J. M. (1997). Grounded theory in practice. Thousand Oaks, CA: Sage.

Street, B. (2003). What's "new" in New Literacy Studies? Critical approaches to literacy in theory and practice. Current Issues in Comparative Education, 5(2), 77-91.

Street, B. V. (1984). Literacy in theory and practice (Vol. 9). Cambridge University Press.

Tiezzi, L. J., \& Cross, B. E. (1997). Utilizing research on prospective teachers' beliefs to inform urban field experiences. The Urban Review, 29(2), 113-125.

Wortham, S., \& Gadsden, V. (2006). Urban fathers positioning themselves through narrative: An approach to narrative self-construction. GSE Publications, 78.

Zeichner, K. (2006). Reflections of a universitybased teacher educator on the future of college-and university-based teacher 
education. Journal of Teacher Education, 57(3), 326-340.

Zeichner, K. (2010). Rethinking the connections between campus courses and field experiences in college- and university-based teacher education. Journal of Teacher Education, 61(1-2), 89-99.

Zeichner, K. (2012). The turn once again toward practice-based teacher education. Journal of Teacher Education, 63(5), 376-382.
Zeichner, K., Ball, A. F., \& Tyson, C. A. (2011). Embracing complexity and community in research on multicultural teacher education. Studying Diversity in Teacher Education, 329-337.

Zeichner, K., Payne, K., \& Brayko, K. (2012). Democratizing knowledge in university teacher education through practice-based methods teaching and mediated field experience in schools and communities. Harvard Educational Review.

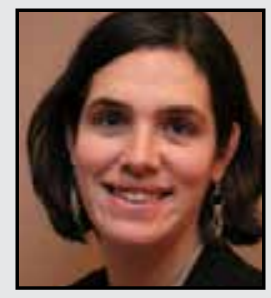

Katrina Bartow Jacobs is currently a Visiting Assistant Professor at the University of Pittsburgh in the Department of Instruction and Learning. She earned her Ph.D. at the University of Pennsylvania in Reading/Writing/Literacy. She was formerly an elementary school teacher, teaching first and fourth grades. Her research interests focus on teacher education and literacy education, with an emphasis on teacher identity, the role of inquiry in teacher education, and issues of social justice and equity within urban schooling.

LINK TO:

http://www.education.pitt.edu/people/profile.aspx?f=KatharineEJacobs 